\title{
\begin{tabular}{l|l|l} 
Jurnal Kependidikan Dasar & $\begin{array}{l}\text { Volume : } \\
\text { Nomor }\end{array} 11$ \\
& Tahun $: 2019$ \\
\hline Islam Berbasis Sains
\end{tabular}
}

\section{Eksistensi Tunagrahita dalam Pembuatan Batik Ciprat}

\author{
Hikma Khilda Nasyiithoh \\ IAIN Ponorogo \\ hikmakhilda@gmail.com
}

\begin{abstract}
The impression of mental retardation as a person who is not independent has been refuted when we see the state of the village caring for the mentally disabled in the village of Simbatan, Nguntoronadi, Kab. Magetan. Mentally retarded people in Simbatan Village were gathered together by the village government and social services and were given training in making "batik ciprat". The research aims to describe the existence of mental retardation in the village of Simbatan in making "batik ciprat". This research is descriptive qualitative, by obtaining research data through interviews, observation, and documentation. The research results showed that people with mental retardation in Simbatan were able to produce works in the form of "batik ciprat". "batik ciprat" is made by splashing "malam" (batik coloring material) into the cloth using a brush. "batik ciprat" was chosen because it allows retardation to do it easily. In addition to producing "batik ciprat" works, other works produced in the form of table cloths and cloth shoes with "batik ciprat" motif.
\end{abstract}

Keywords: ciprat batik; mental retardation.

\begin{abstract}
Abstrak
Kesan tunagrahita sebagai pribadi yang tidak mandiri seperti terbantahkan ketika melihat keadaan kampung peduli tunagrahita yang berada di Desa Simbatan, Nguntoronadi Kab. Magetan. Tunagrahita yang banyak ditemui di Desa Simbatan dihimpun menjadi satu oleh pemerintah desa dan dinas sosial serta diberikan pelatihan pembuatan batik ciprat. Penelitian ini bertujuan untuk mendeskripsikan eksistensi tunagrahita di Desa Simbatan dalam membuat batik ciprat. Penelitian ini termasuk ke dalam jenis deskriptif kualitatif, dengan memperoleh data hasil penelitian melalui wawancara, observasi, dan dokumentasi. Hasil penelitian menunjukkan bahwa penyandang tunagrahita di Simbatan mampu menghasilkan karya berupa batik ciprat. Pembuatan batik dilakukan dengan cara mencipratkan malam (bahan pewarna membatik) ke kain dengan menggunakan kuas. Dipilihnya batik ciprat karena yang memungkinkan tunagrahita bisa mengerjakannya dengan mudah. Selain menghasilkan karya kain batik ciprat, karya lain yang dihasilkan berupa taplak meja dan sepatu kain dengan motif batik ciprat.
\end{abstract}

Kata kunci: batik ciprat; tunagrahita. 


\section{A. Pendahuluan}

Indonesia selain memiliki budaya dan adat istiadat yang beragam, juga memiliki warga yang beragam. Mulai dari mata pencaharian warga hingga pada kondisi keterbatasan yang dimiliki. Salah satu bentuk keterbatasan yang dimiliki adalah warga dengan istilah tunagrahita. Banyak terminologi (istilah) yang digunakan untuk menyebut mereka yang kondisi kecerdasannya di bawah rata-rata. Dalam bahasa Indonesia, istilah yang pernah digunakan, misalnya lemah otak, lemah ingatan, lemah pikiran, retardasi mental, terbelakang mental, cacat grahita, dan tunagrahita. Adapun peristilahan di Indonesia mengenai tunagrahita, mengalami perkembangan seperti berikut :

a. Lemah pikiran, lemah ingatan, digunakan sekitar Tahun 1967

b. Terbelakang mental, digunakan sejak Tahun 1967 hingga tahun 1983

c. Tunagrahita, digunakan sejak Tahun 1983 hingga sekarang dan diperkuat dengan terbitnya Peraturan Pemerintah No. 72/1991 tentang Pendidikan Luar Biasa. Istilah tunagrahita masih digunakan hingga saat ini. ${ }^{1}$

Kemis \& Rosnawati menyatakan bahwa Tunagrahita merupakan individu yang memiliki intelegensi dengan skor IQ sama ataulebihrendahdari70sehinggamenghambat segala aktivitas dalam kehidupannya seperti dalams bersosialisasi, komunikasi dan ketidakmampuan menerima pelajaran yang bersifat akademik. ${ }^{2}$

Anak dengan tunagrahita mempunyai karakteristik sosial emosional sebagai berikut :

1 IGAK Wardani et al., Pengantar Pendidikan Anak Berkebutuhan Khusus (Banten: Universitas Terbuka, 2013).

2 Wardani et al.
- Mengalami kesulitan dalam mempelajari hal baru dan pengetahuan abstrak, cepat lupa dengan apa yang dipelajari jika tidak terus menerus berlatih

- Memiliki cacat fisik dan kurang dalam perkembangan gerak; mayoritas anak dengan tunagrahita berat memiliki keterbatasan dalam gerak fisik, seperti tidak dapat berjalan.

- Mengalami kesulitan mengurus diri sendiri; anak tunagrahita tidak dapat berpakaian, makan dan mengururs kebersihan diri sendiri.

- Kurang mampu berinteraksi; anak tunagrahita ringan dapat bermain bersama anak lain, tetapi anak tunagrahita berat tidak melakukan hal tersebut

- Kerap bertingkah laku kurang wajar secara terus menerus; senang memutar mutar jari di depan wajah dan membentur-benturkan kepalanya atau menggingit dirinya sendiri ${ }^{3}$

Kesulitan yang dihadapi tunagrahita selama ini membuat mereka cenderung sulit beradaptasi dengan orang lain dan lingkungan sekitar. Sebagai akibatnya, mereka cenderung tidak memiliki kegiatan dan hanya bergantung pada orang tua atau orang yang berada di rumah sebagai orang yang membantu dalam kesehariannya.

Kesan tunagrahita yang dikenal dengan pribadi yang tidak memiliki kemampuan dan tidak bisa mandiri tersebut seperti terbantahkan ketika melihat keadaan kampung peduli tunagrahita yang berada di Desa Simbatan, Kecamatan Nguntoronadi, Kabupataen Magetan, Jawa Timur. Berawal dari banyaknya penyandang tunagrahita di sekitar desa Simbatan yang tidak memiliki kegiatan, pemerintah desa dan warga 3 Tri Gunadi, Mereka Pun Bisa Sukses (Jakarta: Penebar Plus, 2011), 141. 
sekitar berinisiatif untuk membentuk kampung peduli tunagrahita. Bekerja sama dengan dinas sosial, tunagrahita yang banyak ditemui di Desa Simbatan dihimpun menjadi satu dan diberikan pelatihan pembuatan batik ciprat. Tunagrahita yang pada awalnya hanya berdiam diri di rumah, kini mereka memiliki ketrampilan membuat batik ciprat. Oleh karena itu, penulis ingin meneliti bagaimana eksistensi tunagrahita di Desa Simbatan dalam menghasilkan karya batik ciprat.

Penelitian terkait ketrampilan tunagrahita dalam membuat batik ciprat sudah beberapa kali dilakukan. Diantaranya yang dilakukan oleh Nur Cahyo Hendro Wibowo dengan judul "Pendampingan Ketrampilan dan Pengembangan Usaha batik Ciprat untuk Sekolah Luar Biasa (SLB) Tunagrahita pada Yayasan Autisma Semarang". Kegiatan dalam penelitian tersebut diawali dengan memberikan pelatihan kepada guru sebagai pengendali dalam membina anak berkebutuhan khusus. Pelatihan dilakukan dengan melakukan percobaan beberapa kali sampai benar-benar bisa menghasilkan karya batik ciprat yang mempunyai motif yang bervariasi. Selanjutnya, peneliti melakukan analisi SWOT dalam pelatihan batik ciprat tersebut. ${ }^{4}$

Penelitian lain yang terkait juga dilakukan oleh Pingki Tantri Novita dalam tulisan yang berjudul " Pembelajaran Ketrampilan Batik Anak Tunagrahita Program Bimbingan A Di Balai Besar Rehabilitasi Sosial Bina Grahita "Kartini" Temanggung Jawa Tengah", peneliti bertujuan mendeskripsikan pembelajaran ketrampilan batik anak tunagrahita dan

\footnotetext{
4 Nur Cahyo Hendro Wibowo, "Pendampingan Ketrampilan Dan Pengembangan Usaha Batik Ciprat Untuk Sekolah Luar Biasa (SLB) Tunagrahita Pada Yayasan Autisma Semarang," Dimas 15 (2015): 85.
}

diperoleh hasil bahwa 1) Perencanaan pembelajaran ketrampilan batik dimulai dengan penyusunan RPP dengan masingmasing standart kompetensi dan kompetensi dasar berdasarkan acuan kurikulum bimbingan. 2). Pelaksanaan pembelajaran dilaksanakan sesuai silabus dan RPP yang telah dibuat oleh pembimbing. 3) hasil evaluasi pembelajaran batik dapat diketahui bahwa nilai penguasaan kemampuan teori dan praktik semua peserta didik telah memenuhi criteria ketuntasan minimal sesuai dengan indicator yang sudah ditetapkan. 4). Hasil karya peserta didik berupa alas/ taplak meja batik dengan teknik ciprat dan jumputan. 5). Kendala yang dihadapi pada saat proses pembelajaran berasal dari faktor peserta didik dan pembimbing. ${ }^{5}$

Dalam penelitian oleh Erlinda dan Ismadi yang berjudul "Pembelajaran Batik Ciprat Bagi Siswa Tunagrahita Ringan di SLB Bhakti Kencana Krikilan Berbah Sleman" diperoleh hasil bahwa 1) Perencanaan guru menyesuaiakan karakteristik anak tunagrahita menggunakan Panduan Kurikulum Pendidikan Khusus SMALB Tunagrahita Ringan. Media pembelajaran menggunakakn contoh karya batik ciprat siswa terdahulu. 2) Proses pembelajaran batik ciprat dirasa mudah bagi peserta didik karena batik ciprat tidak melalui proses pemolaan motif batik yang terkadang terhambat karena keterbatasan peserta didik. Motif yang dihasilkan berupa motif abstrak dengan hasil cipratan alami para peserta didik. 3) Penilaian pembelajaran batik ciprat menggunakan alat ukur non

\footnotetext{
5 Pingki tantri Novita, "Pembelajaran Keterampilan Batik Anak Tunagrahita Program Bimbingan A Di Balai Besar Rehabilitasi Sosial Bina Grahita 'Kartini' B Temanggung Jawa Tengah," Jurnal Pendidikan Kriya, 2016, 1.
} 
tes yang memcakup ranah kognitif, afektif, psikomotorik, dan hasil karya batik ciprat. ${ }^{6}$

Responden dalam ketiga penelitian tersebut adalah siswa/ peserta didik tunagrahita di bawah didikan Sekolah Luar Biasa (SLB) atau lembaga sosial bina grahita. Sedangkan dalam penelitian yang dilakukan oleh penulis, responden adalah warga masyarakat penyandang tunagrahita di sekitar Desa Simbatan yang dalam kesehariannya tidak memiliki kegiatan dengan rata-rata usia mereka adalah usia dewasa.

Berdasarkan ketiga penelitian tersebut dapatditarikkesimpulanbahwatunagrahita yang dipandang kurang atau bahkan tidak memiliki kemampuan, ternyata apabila diberikan pembelajaran dan pelatihan pembuatan batik ciprat mampu menghasilkan suatu karya yang luar biasa, yakni batik. Begitu pula dengan tunagrahita di Desa Simbatan, setelah diberikan pelatihan pembuatan batik ciprat ternyata meraka mampu menghasilkan suatu karya batik ciprat. Apabila terus dikembangkan, tunagrahita di Desa Simbatan, tidak hanya mampu menghasilkan batik ciprat saja, melainkan karya lain seperti taplak meja dan sepatu kain dengan motif batik ciprat.

\section{B. Metode Penelitian}

Penelitian ini merupakan jenis penelitian deskriptif kualitatif. Lokasi penelitian berada di Kampung Peduli Tunagrahita Desa Simbatan, Kecamatan Nguntoronadi, Kabupaten Magetan, Jawa Timur. Sumber data dalam penelitian ini adalah penyandang tunagrahita yang berada di Kampung Peduli Tunagrahita Desa Simbatan yang berjumlah sekitar

6 Erlinda Prima Ayu Cahyaningsih and Ismadi, "Pembelajaran Batik Ciprat Bagi Siswa Tunagrahita Ringan Di SLB Bhakti Kencana Krikilan Berbah Sleman," 2016, 1.
36 orang laki-laki dan perempuan. Untuk memperoleh data di lapangan dalam rangka mendiskripsikan eksistensi tunagrahita dalam membuat batik ciprat, pengumpulan data dilakukan dengan teknik wawancara, observasi, dan dokumentasi.

\section{Hasil dan Pembahasan \\ Kampung peduli tunagrahita}

Kampung peduli tunagrahita Desa Simbatan terbentuk mulai tahun 2015. Terbentuknya kampung peduli tunagrahita tersebut berawal dari banyaknya penyandang tunagrahita di sekitar Desa Simbatan yang tidak memiliki kegiatan. Dari rasa ingin membantu agar kehidupan sehari-hari penyandang tunagrahita lebih mandiri, pemerintah desa dan warga sekitar berinisiatif untuk membentuk kampung peduli tunagrahita untuk memberikan pelatihan batik ciprat. Kampung peduli tunagrahita ini diketuai oleh Bapak Nurwanto dan dibantu oleh beberapa kader seperti kader (pendamping) pembuatan dan pemasaran.

\section{Tempat dan waktu pembuatan batik ciprat}

Kegiatan rutin tunagrahita dalam membuat batik ciprat dilakukan setiap selasa dan jumat sore yang bertempat di Balai Desa Simbatan (Gambar 1). Apabila mendapatkan banyak pesanan batik ciprat, kegiatan bisa dilakukan setiap hari. Kegiatan pembuatan batik ciprat tetap didampingi oleh 4 orang kader pendamping. 


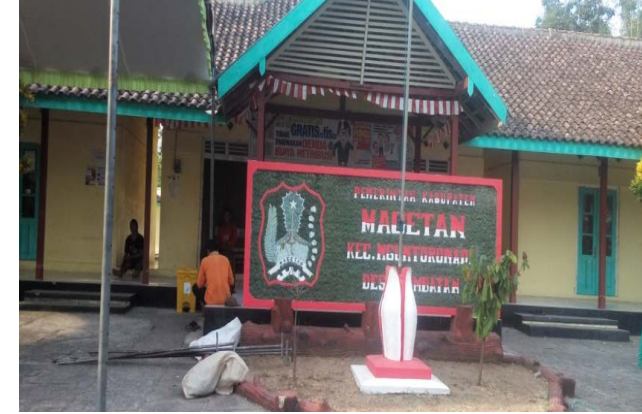

Gambar1 Balai Desa Simbatan

\section{Bahan dan Proses pembuatan batik ciprat}

'Dilihat secara definisi, batik sebenarnya adalah sebuah teknik untuk merintang/menahan warna di atas kain dengan menggunakan malam/lilin. ${ }^{7}$ Batik pada dasarnya merupakan cara menghias sebuah kain dengan tehnik tertentu. Kusrianto mengatakan bahwa teknik yang dipergunakan dalam batik yaitu dengan menggunakan teknik pencelupan dengan perintang warna. ${ }^{8}$ Bahan perintang warna yang digunakan adalah malam. Teknik dalam membatik yang telah dikenal lama diantaranya adalah teknik canting/ tulis, teknik cap, teknik printing, dan teknik celup. Sekarang, muncul teknik baru dalam membatik, yang dikenal dengan batik ciprat. Perbedaan dalam pembuatan batik ciprat tidak menggunakan canting, melainkan menggunakan kuas.

Bahan yang digunakan dalam pembuatan batik ciprat oleh tunagrahita desa simbatan ini pun juga tak jauh berbeda dengan pembuatan batik pada umumnya. Diantaranya kain mori, pewarna, dan "malam". Proses dalam pewarnaan juga sama dengan teknik canting yaitu "malam" terlebih dahulu

\footnotetext{
Iwet Ramadhan, Cerita Batik (Tangerang Selatan: Literati, 2013), 14.

8 Hening Windria, "Batik Kaya Matematika, Memanfaatkan Motif Batik Dalam Kelas Matematika" 1 (2016): 279.
}

direbus sebelum diaplikasikan pada kain. Perbedaannya terletak pada teknik pembuatan. Dalam pembuatan batik, tunagrahita desa Simbatan menggunakan teknik ciprat. Dipilihnya batik ciprat karena yang memungkinkan tunagrahita bisa mengerjakannya dengan mudah, sebab batik ciprat tidak harus dilukis namun pewarna (malam) langsung dicipratkan ke kain dengan kuas. Berdasarakan wawancara penulis dengan $\mathrm{Bu}$ Kitun, salah satu pengurus kegiatan tunagrahita di Desa Simbatan, "Mereka gak bisa mbak kalau pakai canting, gak telaten kalau harus meniup-niup canting, jadi bisanya untuk pengerjaanya pakai kuas". ${ }^{9}$

Kain mori sebagai bahan dasar batik terlebih dahulu dibentangkan pada pipa yang terbuat dari paralon. Kemudian diberi pewarna dasar dengan menggunakan kuas. Setelah pewarnaan rata, malam diciprat cipratkan ke kain dengan menggunakan kuas cat. Pelukisan motif batik juga dilakukan dengan menggunakan kuas. Setelah semua proses selesai, kain dijemur hingga kering kemudian dilepaskan dari pipa pembentang. Proses selanjutnya adalah pencucian kain, perebusan dan penjemuran.

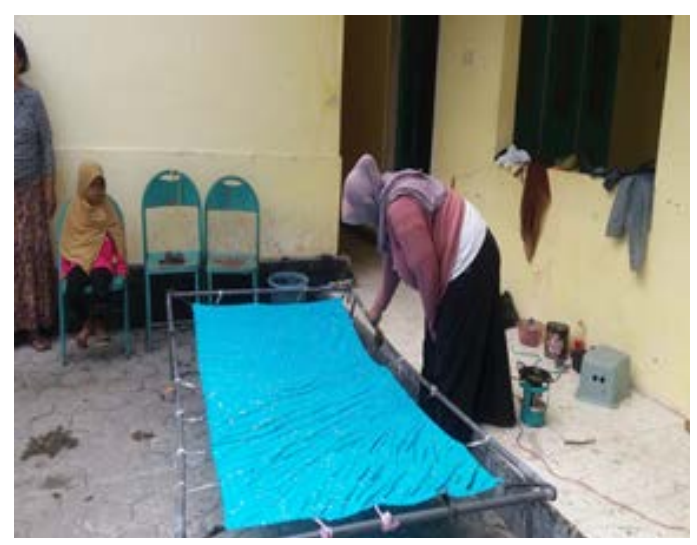

Gambar 2 Proses pembuatan batik ciprat

9 Kitun, "Wawancara" (Magetan, n.d.), 16 September 2018. 


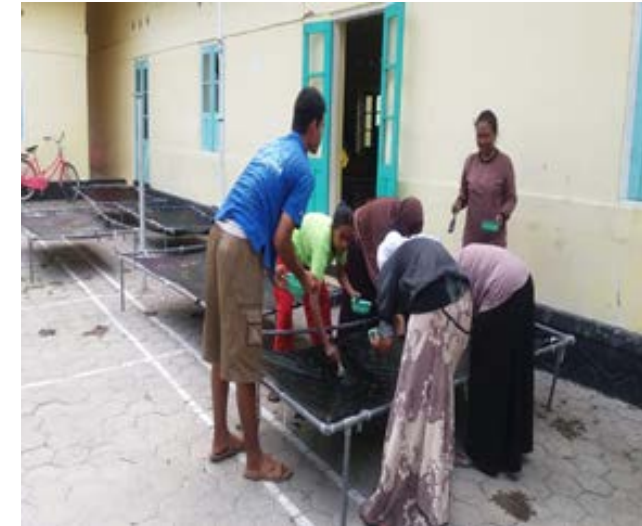

Gambar 3

Proses pembuatan batik ciprat

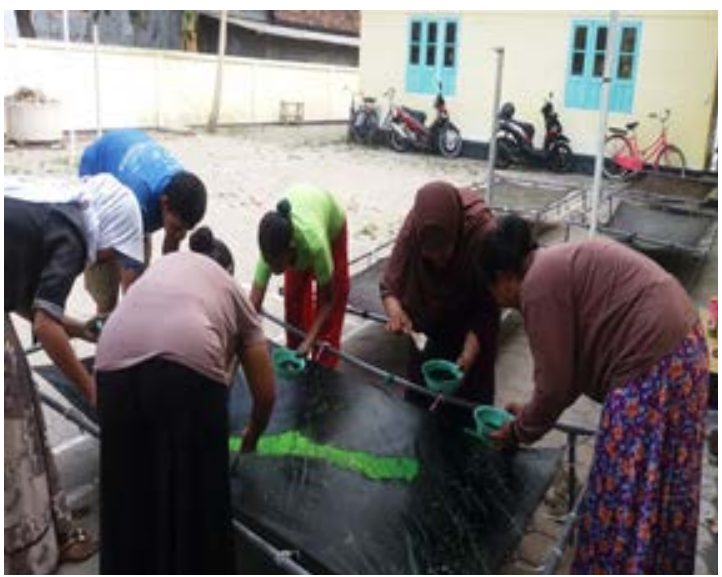

Gambar 4

Proses pembuatan batik ciprat

\section{Hasil karya}

Karya batik ciprat yang dihasilkan berupa kain batik ciprat, sepatu (Gambar 5), dan taplak meja. Motif kain batik bisa dipesan sesuai keinginan pembeli, asalkan motif yang diminta tidak terlalu sulit dan pelukisan motifnya masih bisa dikerjakan dengan menggunakan kuas. Sebagai contoh, motif batik seperti pada gambar 6 . Pemesan meminta motif bunga-bunga pada kain batik yang dipesan. Pelukisan bunga dan daun menggunakan kuas kecil. Namun demikian, motif batik ciprat sebagai khas dari batik ciprat hasil karya tunagrahita desa Simbatan tetap dimunculkan.

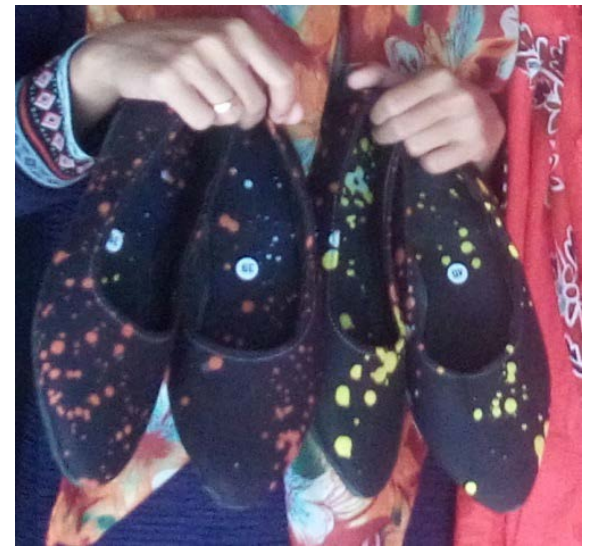

Gambar 5

Sepatu dengan motif batik ciprat

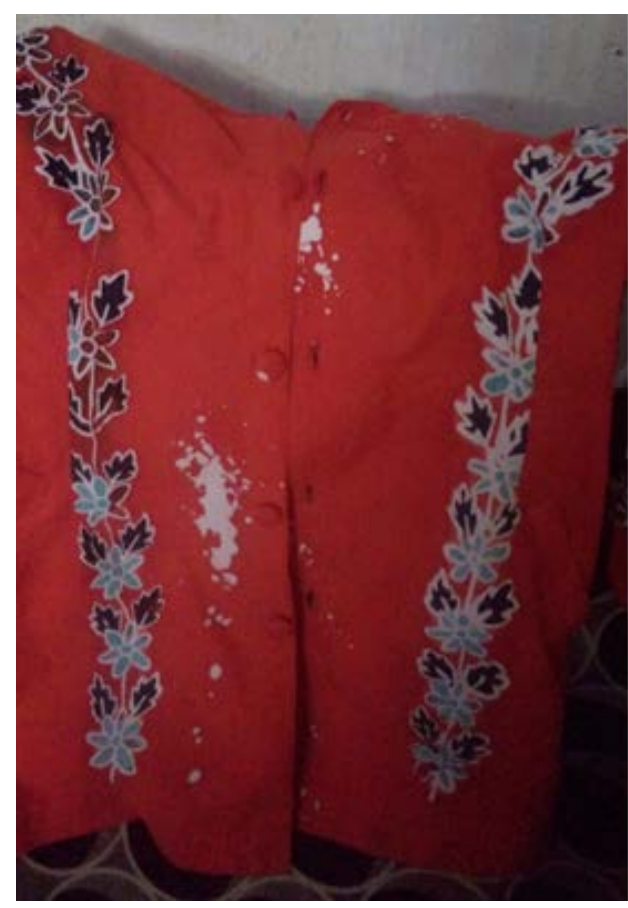

Gambar 6

Baju dari kain batik ciprat

Selain menghasilkan kain, sepatu, dan taplak meja dengan motif batik ciprat, tunagrahita di Desa Simbatan juga menghasilkan karya lain seperti keset, aksesoris, tempat tisu, vas bunga, tempat minum air mineral gelas, dan juga gantungan kunci.

\section{Pemasaran}

Pemasaran hasil karya tunagrahita Desa Simbatan dilakukan oleh Desa, Kecamatan, dinas sosial dan kementerian sosial. Teknik 
pemasaran masih sebatas mulut dan mulut serta secara online. Dalam pemasaran hasil karyanya, tunagrahita Desa Simbatan masih belum memiliki toko/ geleri yang khusus menjual hasil karya nya.

\section{Kendala}

Kendala yang ditemukan dalam pembuatan batik ciprat oleh tunagrahita Desa Simbatan ini diantaranya adalah harus seringnya mengulang pemberian instruksi kepada tunagrahita. Kendala lain yaitu keaktifan dari tunagrahita. Tidak semua tunagrahita aktif dalam kegiatan pembuatan batik ciprat.

\section{E. Kesimpulan}

Tunagrahita di Kampung Peduli Tunagrahita desa Simbatan, Nguntoronadi, Magetan telah mampu menghasilkan karya berupa kain batik ciprat, taplak meja, dan sepatu. Karya lain yang dihasilkan berupa keset, aksesoris, tempat tisu, vas bunga, tempat minum aqua gelas, dan gantungan kunci. Hal ini tentunya membantah kesan tunagrahita yang dikenal dengan pribadi yang tidak memiliki kemampuan dan tidak bisa mandiri. Dengan terus memberikan pelatihan serta pendampingan terhadap tunagrahita, maka tunagrahita yang awalnya tidak memiliki kegiatan, akan mampu menghasilkan karya yang luar biasa.

\section{DAFTAR PUSTAKA}

Cahyaningsih, Erlinda Prima Ayu, and Ismadi. "Pembelajaran Batik Ciprat Bagi Siswa Tunagrahita Ringan Di SLB Bhakti Kencana Krikilan Berbah Sleman," 2016, 1-11.
Gunadi, Tri. Mereka Pun Bisa Sukses. Jakarta: Penebar Plus, 2011.

Kitun. "Wawancara." Magetan, n.d.

Novita, Pingki tantri. "Pembelajaran Keterampilan Batik Anak Tunagrahita Program Bimbingan A Di Balai Besar Rehabilitasi Sosial Bina Grahita 'Kartini' B Temanggung Jawa Tengah." Jurnal Pendidikan Kriya, 2016, 1-12.

Ramadhan, Iwet. Cerita Batik. Tangerang Selatan: Literati, 2013.

Wardani, IGAK, Didi Tarsidi, Tati Hernawati, and Astati. Pengantar Pendidikan Anak Berkebutuhan Khusus. Banten: Universitas Terbuka, 2013.

Wibowo,NurCahyoHendro."Pendampingan Ketrampilan Dan Pengembangan Usaha Batik Ciprat Untuk Sekolah Luar Biasa (SLB) Tunagrahita Pada Yayasan Autisma Semarang." Dimas 15 (2015): 85-108.

Windria, Hening. "Batik Kaya Matematika, Memanfaatkan Motif Batik Dalam Kelas Matematika" 1 (2016): 279-91. 